\title{
Is the Chilean Diet a Mediterranean-type Diet?
}

\author{
JAIME ROZOWSKI and ÓSCAR CASTILLO
}

Department of Nutrition and Diabetes, Faculty of Medicine, Pontifical Catholic University of Chile, Santiago, Chile

\begin{abstract}
Food intake in Chile has changed markedly in the last decades, showing an increase in fat consumption and presently a small fruit and vegetables intake. A parallel is made between the Chilean and Mediterranean diet (mainly the one from Spain, Italy, and Greece), both currently and from 50 years ago. The main differences and similarities are based on food availability. Although Chilean diet seems to be approaching the traditional Mediterranean diet of the 60's, there is concern about changes that are moving away from Chilean traditional diet and towards a western one. A new food pyramid for Chile is proposed based on the traditional

Mediterranean-type diet.
\end{abstract}

\section{INTRODUCTION}

The last decades have witnessed a radical change in the way we feed ourselves. The access to food and its availability have markedly increased in this period of time and the establishment of large food outlets has made purchasing items very simple. This is true not only for the well-to-do but also for the poor population in many developing countries.

This pattern of change has also been present in Chile. In the last 5 decades malnutrition has practically disappeared, and infant mortality rate has decreased from $120 / 1000$ live births to less than $7 / 1000$ live births nowadays (1). Unfortunately, in the same period of time we have seen a dramatic increase in the prevalence of obesity, currently at levels comparable to those of developed countries (2). Nevertheless, health indicators, in general, have improved markedly in the country (1).

Recently the World Health Organization developed an indicator called HALE (Healthy Life Expectancy at Birth), which also takes into consideration the appearance of disease during the life of an individual (3). Table I shows the HALE indicator for some selected countries. The Chilean HALE is one of the highest in South America, and is very similar to the one in the US. Although in Chile, HALE is still lower than in European Mediterranean countries, this measurement suggests that the Chilean environment is more favorable than that of other countries in South America. Obviously diet plays an important role here, but there are other aspects worth establishing. Chilean health expenditures per capita (US\$ 654) are lower than in the majority of the more developed countries in South America, with the exception of Cuba (US\$ 303) and Costa Rica (US\$ 450), and substantially lower than in the US and in the Mediterranean countries mentioned previously (4). The country also has a relatively low number of physicians / 100,000 inhabitants (140) compared to 530 in Cuba, 279 in the US, 303 in France, 424 in Spain, 554 in Italy, and 392 in Greece (3).

So what is so special about the Chilean environment that makes it favorable to the health of its population? Although there are many factors influencing the outcome, we will concentrate on the Chilean diet and its comparison with the one from 
Mediterranean countries, since their diet has been widely recognized as a healthy one (5-15).

One of the problems that we encounter in analyzing the Chilean diet is the lack of national nutrition surveys. The first was done in 1960 (16) and the second (and last one) was performed in 1974 (17). Therefore, we have no idea of the composition of the Chilean diet at a national level. The information we do have comes from studies in relatively small samples obtained mainly from the large cities or that are non-representative. For this reason, we decided to analyze the information provided by FAO in terms of availability of food (18). Although we recognize that this may be different from what is actually consumed by the individual, it is the only data currently available that can be used to compare diets in different countries.

\section{COMPARISON OF THE CHILEAN AND MEDITERRANEAN DIET}

Table II shows the percentage of total calories contributed by different foods to the diet of Chile and Spain in the period

TABLE I

Healthy life expectancy at birth (HALE) in selected countries.

\begin{tabular}{lc}
\hline Country & $\begin{array}{c}\text { HALE } \\
\text { (years) }\end{array}$ \\
\hline Italy & 71.2 \\
Greece & 71.0 \\
France & 70.7 \\
Spain & 70.6 \\
USA & 67.2 \\
Cuba & 65.9 \\
Chile & 65.5 \\
Costa Rica & 65.3 \\
Argentina & 63.9 \\
\hline
\end{tabular}

Source: Reference 3

TABLE II

Calories availability contributed by food items in Spain and Chile as percentage of total calories.

\begin{tabular}{lcc}
\hline & $\begin{array}{c}\text { Chile 1993-95 } \\
\text { \% Calories }\end{array}$ & $\begin{array}{c}\text { Spain 1993-95 } \\
\text { \% Calories }\end{array}$ \\
\hline Cereals & 41 & 23 \\
Tubers & 3.8 & 4.8 \\
Sugar & 16 & 8.8 \\
Legumes & 1 & 2,7 \\
Fruits and vegetables & 6 & 7.2 \\
Vegateble oil & 9 & 19.5 \\
Red meet & 7.6 & 9.6 \\
Poultry & 3 & 2.5 \\
Fish & 2 & 2.3 \\
Dairy products & 6.2 & 7.9 \\
Others & 4.4 & 11.7 \\
\hline
\end{tabular}

Source: Reference 18 
between 1993-1995. As we can see, Chileans consume a much higher proportion of cereals (mainly bread) and sugar than Spaniards. We also consume less tubers, legumes, fruits and vegetables, vegetable oil, and dairy products.

In order to expand this analysis we compared food availability in grams/day in Chile, Italy, Greece, and Spain, using the Spanish data as the unit (Fig 1). As observed in Figure 1, we do consume more cereals than Spain but less than Italy or Greece. Our meat consumption (which includes chicken, a main staple in Chilean diet) is lower than in the three Mediterranean countries. The same happens for dairy products, fruits and vegetables, vegetable oil, and legumes. Potato consumption in Chile is lower than in Spain and Greece but higher than in Italy. We consume more eggs than the Mediterranean countries and substantially less fish than Spain and Greece and more than Italy.

This information indicates that Chile shows a varied pattern of food availability compared to Mediterranean countries.
Nevertheless, several reports have shown that the diet of Mediterranean countries has undergone changes with time $(19,20)$. We therefore decided to study, again using FAO data, which changes have taken place with time in the availability of food from 1961 to 1999 in Chile, Spain and Italy (18).

Table III shows the changes in total calories in the three countries. In all of them there has been an increase in availability, although the increase has been slower in Chile. What is interesting to point out is that calorie availability in Chile is now at the level of availability in Spain around 1970, and we are approaching the availability of Italy in 1961. A similar pattern was observed for the contribution of cereals, dairy products, and fruits to total calories (Table III). Contribution of vegetables to total calories has decreased in Spain and Chile and increased in Italy, while fish availability has increased in all of them (data not shown). Nevertheless, fish consumption in Italy and Chile is much lower than in Spain. In terms of availability of vegetable oil, Chile is now at the level of

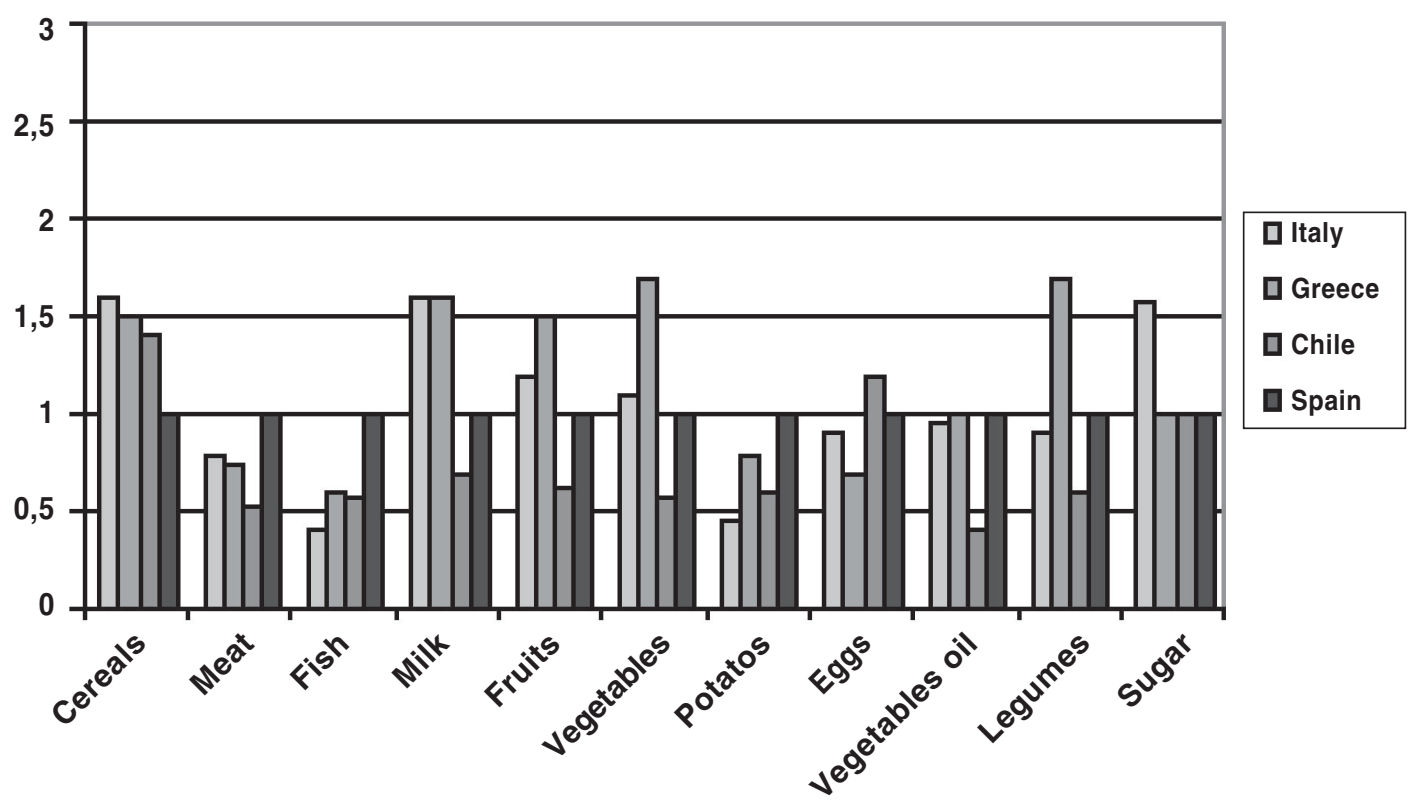

Figure 1. Relative consumption of foods in Spain (unit), Chile, Italy, and Greece, 1999. Source: Reference 18. 
TABLE III

Total calories availibality and contribution of total cereals, dairy products, fruits and vegetable oil to total calories in Chile, Spain and Italy, 1961 and 1999

\begin{tabular}{llrr}
\hline & Country & 1961 & 1999 \\
\hline Total Calories & Spain & 2631 & 3353 \\
& Italy & 2914 & 3629 \\
& Chile & 2476 & 2858 \\
Cereals: \% Calories & Spain & 40,2 & 21,9 \\
& Italy & 44,6 & 21,9 \\
& Chile & 48,1 & 39,3 \\
Dairy: \% Calories & Spain & 5,8 & 7,7 \\
& Italy & 6,2 & 7,6 \\
& Chile & 4,9 & 5,7 \\
Fruits: \% calories & Spain & 2,7 & 4 \\
& Italy & 4,5 & 4,5 \\
Fish: \% calories & Chile & 1,9 & 3,2 \\
& Spain & 1.8 & 2.3 \\
& Italy & 0.7 & 1.1 \\
Vegetable oils: \% Calories & Chile & 0.5 & 1.2 \\
& Spain & 12,1 & 19,8 \\
& Italy & 10,4 & 17,3 \\
\hline
\end{tabular}

Italy in 1961, with all 3 countries showing an increase in the availability of this product.

So what can we conclude from these data? Table IV shows the proportion of calories contributed by different foods but this time comparing Spain in 1961 to Chile in 1993-95. As we see, the availability of cereals, fruits and vegetables (grouped together), dairy products, and fish are similar to the consumption of Spain at that time. However, Chileans consume relatively fewer legumes, tubers, vegetable oil, and more red meat and sugar than Spaniards did at that time.

The information showed here indicates that in all these countries there has been a change in the pattern of food availability (and therefore, in food consumption). Although Chile seems to be moving in a favorable way, we have observed an increase in the consumption of sugar and other sweeteners, an increase in the consumption of fats and of prepared meats, which are usually rich in fat and salt (21, 22). Probably of great importance has been the decrease in the amount of exercise in the population $(23,24)$.

\section{FOOD GUIDELINES}

The current guideline for food intake in Chile is the Food Pyramid (Fig 2) (25). This pyramid gives large importance to cereals, potatoes, and fresh vegetables. The first two already are highly consumed in Chile. The pyramid also gives guidelines based on portions consumed per day, which is confusing to the majority of the population. Here we propose a new type of pyramid, stressing the Mediterranean-style of consumption (J. Rozowski, O. Castillo, I. Urquiaga and F. Leighton, unpublished). As shown in Figure 3, this pyramid stresses the consumption of whole-grain vegetables, and of prepared dishes that have always been an integral part of our diet. This guideline also recommends exercise, intake of milk and dairy products, and a moderate consumption of wine. We feel very strongly that wine intake in moderate amounts (up to 1 glass/day in women and 2 glasses/day in men) has already shown to provide health benefits specially when combined with a Mediterranean-style diet (26-31).

The reason to recommend traditional food preparation is because the preservation 


\section{TABLE IV}

Calories availability contributed by food items in Spain and Chile as a percentage of total calories.

\begin{tabular}{lcc}
\hline & $\begin{array}{c}\text { Spain 1961 } \\
\text { \% Calories }\end{array}$ & $\begin{array}{c}\text { Chile 1993-95 } \\
\text { \% Calories }\end{array}$ \\
\hline Cereals & 40.2 & 41 \\
Tubers & 9 & 3.8 \\
Sugar & 7.6 & 16 \\
Legumes & 3.4 & 1 \\
Fruits and Vegetables & 6.7 & 6 \\
Vegetable oil & 12.1 & 9 \\
Red meet & 3 & 7.6 \\
Poultry & 0.3 & 3 \\
Fish & 1.8 & 2 \\
Dairy products & 5.8 & 6.2 \\
Others & 10.1 & 4.4 \\
\hline
\end{tabular}

Source: Reference 18
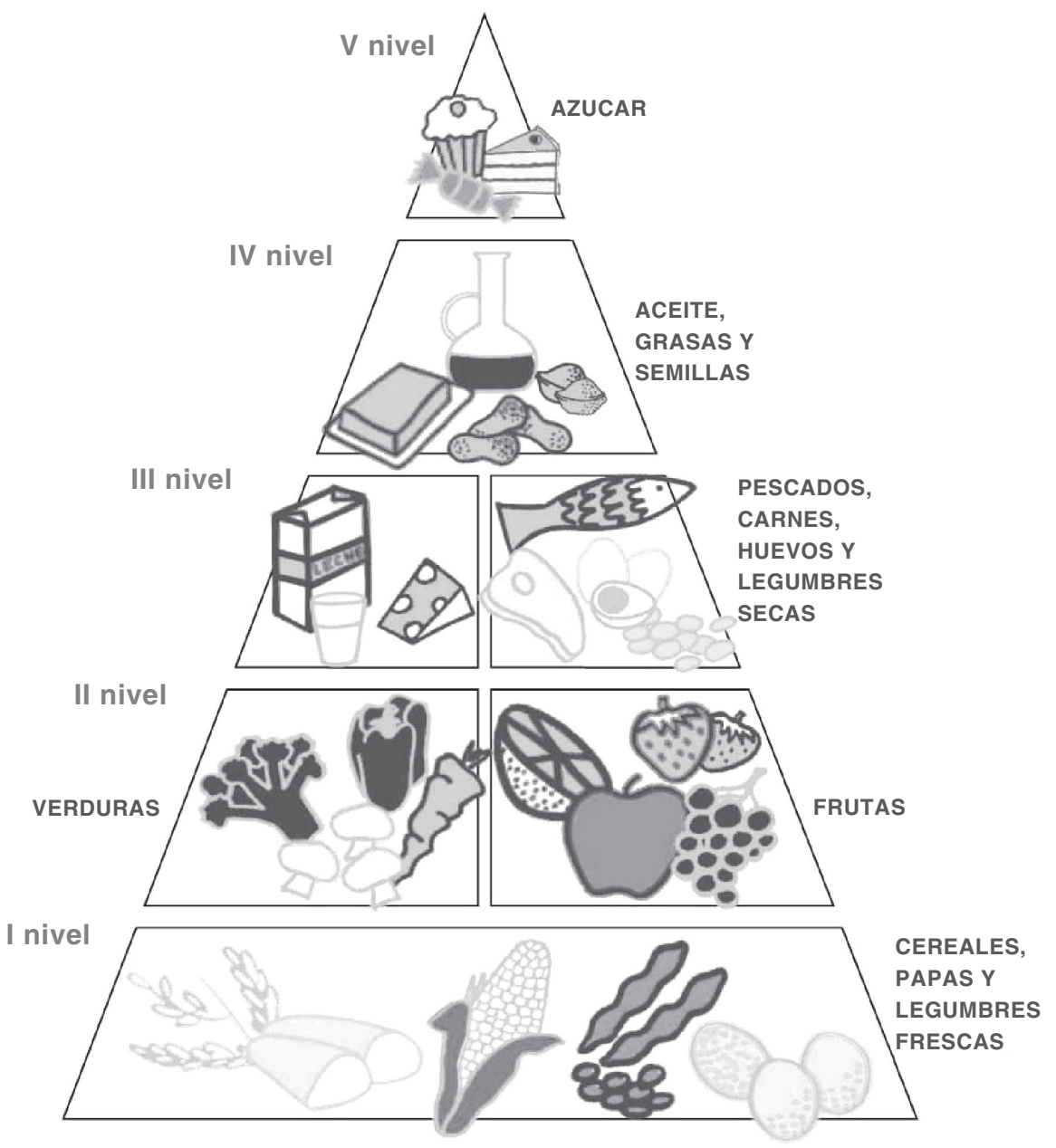

Figure 2. Chilean food pyramid. Source: Reference 22. 


\section{PIRAMIDE DE LA DIETA MEDITERRANEA EN CHILE}

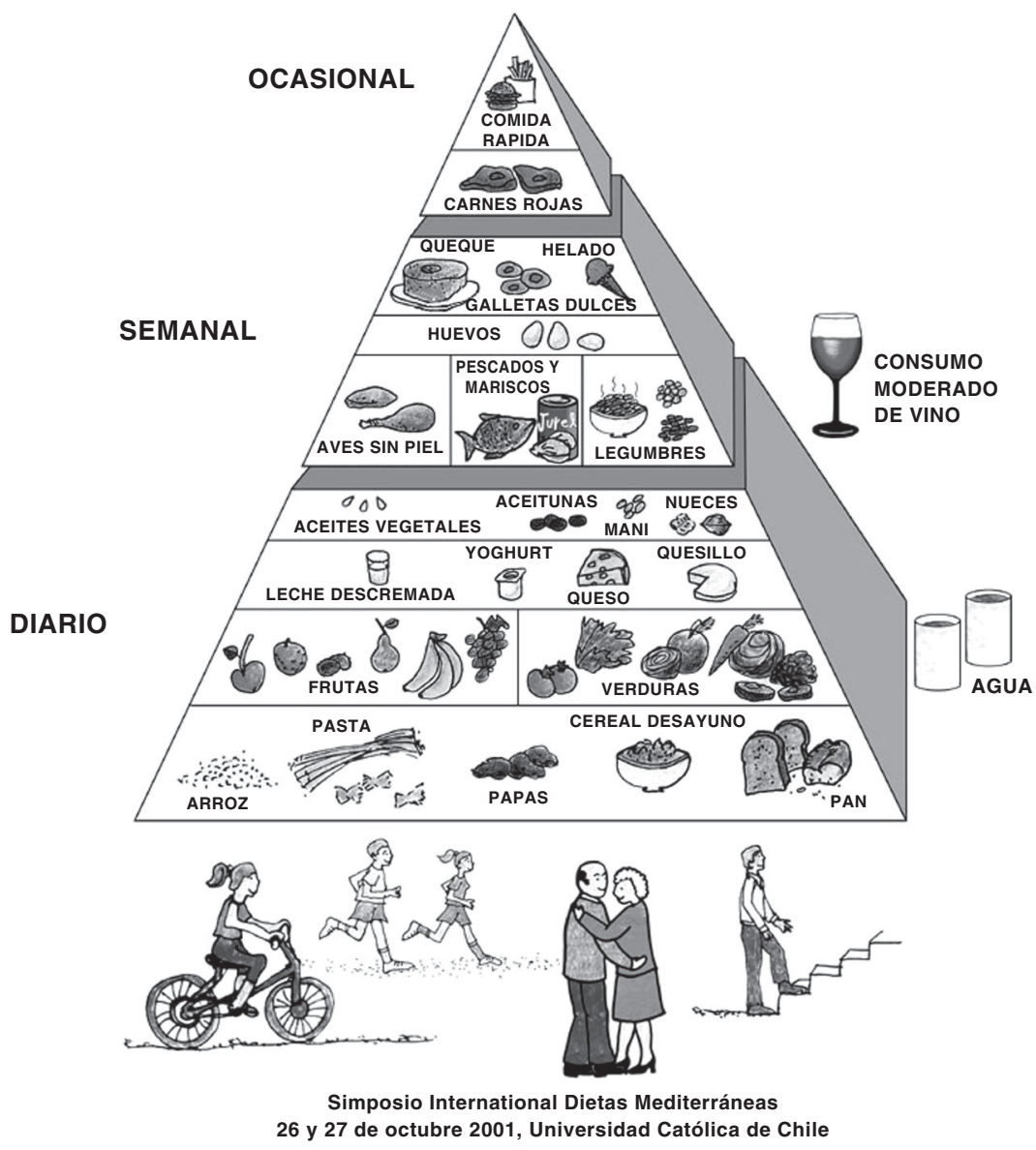

Figure 3. Proposed Mediterranean food pyramid for Chile. Source: J Rozowski, O Castillo, I Urquiaga, F. Leighton, unpublished.

of traditional Chilean dishes like porotos con riendas (beans and spaghetti), pastel de choclo (a combination of corn and ground meat), empanadas (ground meat and onions turnover), mariscal (a combination of fish and seafood), all Mediterranean-style dishes, will maintain a pattern of eating conducive to less incidences of cardiovascular disease and other chronic afflictions.

\section{ACKNOWLEDGEMENTS}

This work was partially supported by the program "Molecular Basis of Chronic
Diseases." The authors would like to thank the expert help of Ms. Marisol Caceres in the preparation of this manuscript.

\section{REFERENCES}

1. MINISTRY OF HEALTH, Chile. www.minsal.cl accessed 5 December 2003.

2. ROZOWSKI J, ARTEAGA A. (1997) El problema de la obesidad y sus alarmantes características en Chile. Rev Med Chile 125: 217-224.

3. WORLD HEALTH ORGANIZATION. http:// www3.who.int/whosis/hale. accessed 11 November 2003

4. PAN AMERICAN HEALTH ORGANIZATION (2002) Health in the Americas. Washington, PAHO. Volume I and II. 
5. TRICHOPOULOU A, LAGIOU P (1997) Healthy traditional Mediterranean diet: An expression of culture, history and lifestyle. Nutr Rev 55 (11): 383388

6. HELSING E (1995) Traditional diets and disease patterns of the Mediterranean, Circa 1960. Am J Clin Nutr 61 (Suppl): 1329S-1337S

7. SERRA-MAJEM LL, RIBAS L, TRESSERRAS R, NGO J, SALLERAS LL (1995) How could changes in diet explain changes in coronary heart disease mortality in Spain? The Spanish paradox. Am J Clin Nutr 61 (Suppl): 1351S-1359S

8. RENAUD S, DE LORGERIL M, DELAYE J, GUIDOLLET J, JACQUARD F, MAMELLE N, MARTIN J, MONJAUD I, SALEN P, TOUBOL P (1995) Cretan Mediterranean diet for prevention of coronary heart disease. Am J Clin Nutr 61 (Suppl): 1360S-1367S

9. TAVANI A, LA VECCHIA C (1995) Fruit and vegetable consumption and cancer risk in a Mediterranean population. Am J Clin Nutr 61 (Suppl): 1374S-1377S

10. KUSHI L, LENART E, WILLET W (1995) Health implications of Mediterranean diets in light of contemporary knowledge. 1. Plants foods and dairy products. Am J Clin Nutr 61 (Suppl): 1407S-1415S

11. KUSHI L, LENART E, WILLET W (1995) Health implications of Mediterranean diets in light of contemporary knowledge. 2. Meat, wine, fats and oil. Am J Clin Nutr 61 (Suppl): 1416S-1427S

12. MISIOLI F, GALLI C (1998) The effect of minor constituents of olive oil on cardiovascular disease: New findings. Nutr Rev 56 (5): 142-147

13. TABAK C, FESKENS EJM, HEEDERICK D, KROMHOUT D, MENOTTI A, BLACKBURN H W (1998) Fruit and fish consumption: a possible explanation for population differences in COPD mortality (the seven countries study). Eur J Clin Nutr 52: 819-825

14. HERTOG M, KROMHOUT D, ARAVANIS C, BLACKBURN H, BUZINA R, FIDANZA F (1995) Flavonoid intake and long-term risk of coronary heart disease and cancer in the Seven Countries Study. Arch Int Med 155: 381-386

15. MEZZANO D, LEIGHTON F, MARTÍNEZ C, MARSHALL G, CUEVAS A, CASTILLO O, PANES O, MUÑOZ B, PÉREZ DD, MIZÓN C, ROZOWSKI J, SAN MARTÍN A, PEREIRA J. (2001) Complementary effects of Mediterranean diet and moderate red wine intake on haemostatic cardiovascular risk factors. Eur J Clin Nutr 55: 444-451.

16. ICNND. Nutrition Survey, Chile, March - June 1960. A report by the Interdepartmental Committee of Nutrition for National Defence. Washington, DC, 1961

17. MINISTRY OF HEALTH, CHILE (1976) Encuesta continuada sobre el estado nutricional de la población chilena (ECEN). Julio 1974 - Junio 1975. Santiago de Chile.

18. FOOD AND AGRICULTURAL ORGANIZATION (2001) FAO's Statistical Data Bases. Country Food Balance Sheets, 1964-1996. <http://apps.fao.org/page/ collections? subset=agriculture $>$. Accessed 10 October 2003.

19. SIMOPOULOS AP, SIDOSSIS LS (2000) What is so special about the traditional diet of Greece. In SIMOPOULOS AP, VISIOLI FN (eds) Mediterranean Diets. World Rev Nutr Diet vol 87: Basel, Karger pp: 24-42.

20. SIMOPOULOS AP (2004) Omega-3 Fatty Acids and Antioxidants in Edible Wild Plants. Biol Res 37: 263-277

21. ALBALA C, VIO F, KAIN J, UAUY R (2001) Nutrition transition in Latin America: The case of Chile. Nut Rev 59: 170-176.

22. VALENZUELA A, SANHUEZA J; NIETO S. (2003) Cholesterol oxidation: Health hazard and the role of antioxidants in prevention. Biol Res 36: 291-302

23. JADUE L, VEGA J, ESCOBAR MC, DELGADO I, GARRIDO C, LASTRA P, ESPEJO F, PERUGA A (1999) Factores de riesgo para las enfermedades no transmisibles: Metodología y resultados de base del programa CARMEN (Conjunto de Acciones para la Reducción Multifactorial de las Enfermedades no Transmisibles). Rev Med Chile 127: 1004-1013.

24. BURNEIKO RC, DINIZ YS, FAINE LA, GALHARDI CM, PADOVANI CR, NOVELLI ELB, CICOGNA AC. (2004) Impact of the training program on lipid profile and cardiac health. Biol Res 37: 53-59

25. CASTillo C, UAUY R, ATALAH E (1997) Guías de Alimentación para la población chilena: Santiago, Ministerio de Salud. pp. 129-149.

26. BERGER K, AJANI UA, KASE CS, GAZIANNO JM, BURING JE, GLYNN RJ, HANNEKENS CH (1999) Light-to-moderate wine consumption and the risk of stroke among US male physicians. New Engl J Med 341: 1557-1564.

27. WANNAMETTHEE SG, SHARPER AG (1999) Type of alcoholic drink and risk of major coronary heart disease events and all-cause mortality. Am J Public Health 89: 685-690.

28. DE LORGERIL M, SALEN P (1999) Wine ethanol, platelets, and Mediterranean diets. Lancet 353: 1067.

29. DE LORGERIL M, MARTIN JL, MONJAUD I, DELAYE J, MAMELLE N (1999) Mediterranean diets, traditional risk factors, and the traditional risk factors, and the rate of cardiovascular complications after myocardial infarction: final report of the Lyon Heart Study. Circulation 99: 779-785

30. NAIR MP, KANDASWAMI C, MAHAJAN S, NAIR HN, CHAWDA R, SHANAHAN T, SCHWARTZ SA: (2002) Grape seed extract proanthocyanidins downregulate HIV- 1 entry coreceptors, CCR2b, CCR3 and CCR5 gene expression by normal peripheral blood mononuclear cells. Biol Res 35: 421-431

31. ROMANQUE P, URIBE-ECHEVARRÍA S, MATAMALA R, FLORES JM, URIBE M, VIDELA LA. (2003) Influence of grape seed bioflavonoids on ischemia-reperfusion liver injury in rats. XLVI Reunión Anual de la Sociedad de Biología de Chile. Biol Res 36: R-35 